\title{
1. Introduction to Water Markets: an overview and systematic literature review
}

\author{
Sarah Ann Wheeler and Ying Xu
}

\section{$1.1 \quad$ PREFACE}

This book, Water Markets: A Global Assessment, includes chapters written by water policy expert scholars highlighting the extent of water markets in 20 countries (and across 28 country areas/basins) around the world. Our case studies include countries within Africa, Asia, Europe, North America, Oceania and South America. The aims of this book are: (1) to provide information on the adoption of water markets around the world; (2) to clarify the range of contexts and issues in which water markets successfully emerge (through the application of a water market readiness framework); and (3) to provide practical insights and guidance on water markets for water managers, academics and research students, industry organisations and government policy-makers. This chapter provides an introduction and a systematic review of the water market literature to date.

\subsection{BACKGROUND}

There are grave concerns regarding future trends in water scarcity across the world, and the challenge of reconciling water supply and demand will intensify as water extractions increase (Barbier, 2019; Grafton et al., 2018). Water issues are often described as a 'wicked problem' because they have multiple, interconnected causes; whilst having many possible solution perspectives (Grafton and Wheeler, 2015; Quiggin, 2001). Hanemann (2006) describes nine economic aspects of water that presents issues for its management: (1) water has both private and public good aspects; (2) water's mobility; (3) water's variability; (4) cost of water; (5) price of water; (6) essentialness of water; (7) heterogeneity of water; (8) fallacy/misconception of using average value; and (9) benefits of water. 
Policy-makers have a range of options to improve water management and allocation, and these very broadly fall into water supply augmentation and water demand management. Supply augmentation - otherwise known as 'hard' infrastructure or engineering solutions to increase water supply (for example, dam, irrigation infrastructure and weir construction) or substitution (for example, desalinated water) - has traditionally been the most promoted because it offers a technical and relatively rapid (and occasionally efficient where there are low marginal costs) method to address water scarcity (Wheeler and Garrick, 2020). Water demand-side management - otherwise known as 'soft' infrastructure and governance - includes educational measures (for example, information and campaigns), regulatory and/or planning processes (for example, legislation and regulation) and economic incentives (for example, economic pricing, subsidies and/or property right changes that allow water markets) (Wheeler and Garrick, 2020). Ideally both demand and supply responses should be integrated to address water security; however, this is frequently not the case (Barbier, 2019; Griffin, 2006; Sadoff et al., 2015).

Given that the choice of cost-effective supply augmentation projects is diminishing around the world, increasingly water demand management, and in particular water markets, will be further considered and implemented to address water scarcity and quality issues. However, little is known about the applicability of water markets, and what advice practitioners can use to assess how suitable their water resource situation is for water markets.

Water markets are often identified as an important way forward for addressing scarce water supply and increasing demand (Gómez Gómez et al., 2018). Previous books on water markets include (but are not limited to) Easter et al. (1998), Easter and Huang (2014) and Maestu (2013). Economists in particular believe in the power of markets to effectively and efficiently reallocate resources at the margin of use, and many argue that water trading is currently underutilised as a management option. On the other hand, there are many critics of water markets, arguing that 'water is too different to sell' (Griffin et al., 2013, p. 2). Griffin et al. (2013, p. 3) summarise this view of water trading opponents as espousing a water-is-different view that exaggerates biological requirements for water, confuses capital scarcity with water scarcity, seeks to preserve agrarian economies and claims public entitlement to water. On the other hand, Griffin et al. (2013) state that some economists over-emphasise the 'water is no different from other commodities' argument, and have too much faith in the market system resulting in an efficient economy.

We agree with Griffin et al. (2013) that water is sufficiently different to other commodities to mean that water markets are not automatically a panacea, and that certain water market failures may mean a net cost for society. There is a need for a variety of conditions to be met for water markets to be successful. 
Indeed, water markets are not an easily adopted or implemented solution, often requiring significant time periods and political/financial investment.

\subsection{WHAT IS WATER TRADING?}

Water trading occurs in water markets, and can be defined as the process of buying and selling water licences (also called entitlements or rights). Three broad types of water trading can be defined: (1) short-term or temporary transfers of water (also known as water allocation trade); (2) medium-term leasing of water allocations to secure access to water for a period of time specified in a contract (also known as water leasing); and (3) permanent transfers of water entitlements - namely: (a) the ongoing property right to either a proportion or fixed quantity of the available water at a given source (also known as water entitlement trading); and (b) water delivery rights, that is, the right to have water delivered (Wheeler and Garrick, 2020).

In short, formal water markets involve reforming water law to transform water public property rights to a situation where some water use rights are divisible, transferable, privately managed and can be bought or sold (in whole or part) (Griffin et al., 2013). Formal water trading arrangements may comprise sanctioned rules, processes, catchment areas managed by governments and/or communities. Hence, water trading can change the location, timing and technical efficiency of water use (Easter et al., 1999; Howe et al., 1986). Formal water markets have evolved widely in the world since the 1970s (Chong and Sunding, 2006), and exist in differing stages across many countries in the world, as illustrated in this global water markets book. Formal water markets can be slow to develop in some regions for a number of reasons, such as local political circumstances and the interrelated nature of water use (for example, return flows) (Vaux and Howitt, 1984; Young, 1986).

Water markets can also be established informally, which typically involves water users located in a specific region or sharing a water resource. Informal water trading arrangements, for example, can include arrangements between neighbours and come in diverse forms (for example, private tube-wells in India or informal swapping of water in the United States, Spain and Mexico) (De Stefano and Hernández-Mora, 2016; Mukherji, 2008).

Another form of water markets includes water quality trading (which is similar to carbon emission trading). It involves regulation of the discharge of point sources (for example, industrial or urban) and allows trading of credits between polluters, with money generated often being used to encourage activities to reduce discharge of nutrients from non-point sources (for example, agriculture). The remainder of this book concentrates mainly on water quantity markets, but for further discussion on water quality markets see Uchida et al. (2018) and Leonard et al. (2019). 


\subsection{EVALUATING WATER MARKETS}

As elaborated further in Chapter 2, there are many ways to evaluate the performance of water markets. Water allocation regimes, such as water markets, typically aim to comply with economic efficiency terms (focusing on wealth creation by a resource) and social equity considerations (focusing on the wealth distribution among sectors and individuals) (Dinar et al., 1997). The three distinct forms of economic efficiency associated with water markets are:

1. Allocative efficiency: improving water resource short-term decision-making to help reflect seasonal conditions (for example, weather, commodity price adjustments, cropping choices) is facilitated by water temporary trade.

2. Dynamic efficiency: improving water resource structural or long-term decision-making to reflect new investment opportunities, regulatory shifts in access arrangements (for example, extraction limits or embargos) or personal strategic choices (for example, retirement), which is best achieved through water permanent trade.

3. Productive efficiency: water price changes (both temporary and permanent) offer incentives for the efficient use of water resources as either an investment or input for productive outcomes.

Grafton et al. (2011) introduced an integrated framework to assess and compare the institutional foundations, economic efficiency and environmental sustainability of water markets around the world. The framework highlights important linkages between water market development, institutional constraints and management goals, and helps to identify which water markets contribute to integrated water resource management, which features of water markets require further development and how water governance can be improved (Grafton et al., 2011).

Grafton et al. (2016) provide extensive commentary about various arguments for and against water markets, including: privatisation (allocation of individual rights), deregulation (diminishment of the regulatory role of public organisations), decentralisation (transfer of decision-making and responsibility to a subsidiary level of authority), corporatisation (shift from public to corporate ownership), commercialisation (adoption of business models of practice and decision-making), marketisation (use of markets to determine use) and resource commodification (treatment of natural resources, including water, as a market good). Often those who argue against markets do so because they believe markets are a tool of global capitalism that results in appropriative privatisation, where state or private actors obtain water resources (without meaningful compensation) previously held in common ownership. However, 
as Griffin et al. (2013) and Grafton et al. (2016) emphasise, there is a clear need to distinguish between infrastructure privatisation and water licence privatisation. Also, while there may be examples of privatisation leading to appropriation, the issue that must be focused upon is whether this is the market's fault, or whether it is a result of the institutions that surround markets and market failure. Understanding market failure and preconditions needed for water markets is critical for their success.

\subsection{WHAT HAS THE WATER MARKET LITERATURE STUDIED TO DATE?}

To understand the focus and overview of the water market literature around the world, we conducted a search of the literature from January 1970 to December 2019 in the electronic databases Web of Science, ScienceDirect, ProQuest Central, Earth, Atmospheric and Aquatic Science Database and Google Scholar. The phrases 'water market', 'water trading', 'water trade', 'groundwater markets', 'water rights', 'water entitlements' and 'water allocation' were used as search terms for title, keywords and anywhere in the text. A flow chart of the literature selection process is included in Figure 1.1.

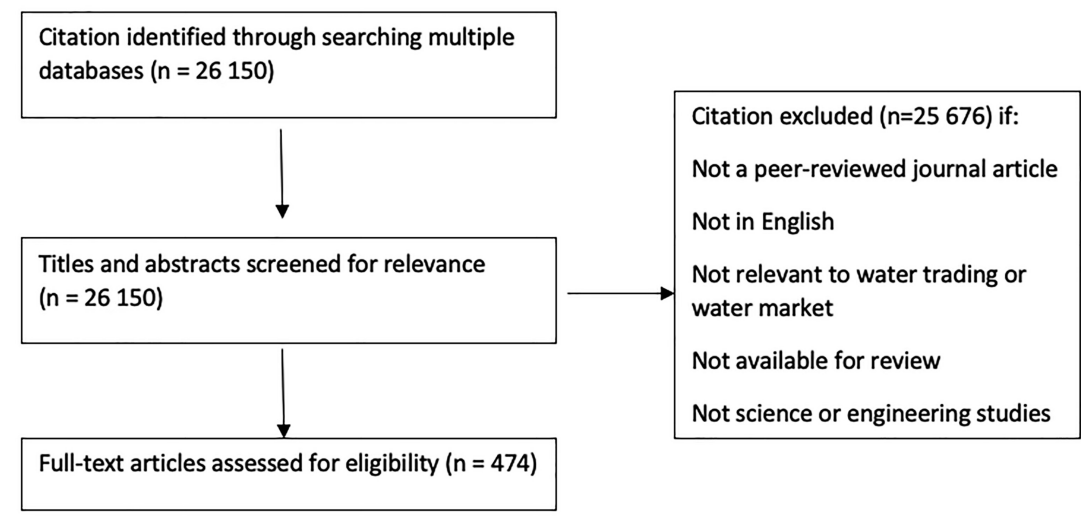

Figure 1.1 Systematic review of water market literature, 1970-2019

Our search was restricted to published English language studies, peer-reviewed journal articles relevant to water market/trading. After further excluding science and engineering studies and those focusing on saltwater or bottled water, there were 465 highly relevant studies on freshwater markets (including both surface water and groundwater) from social science perspectives. These 465 selected publications are further analysed below. 
Figure 1.2 shows the trend of publication numbers of all water market/ trade-related studies and studies titled with 'water market/trade'. The number of all water market/trade-related studies increases significantly from 1970 to 2019 , but the share of studies titled with 'water market/trade' increases only slightly every year. Since the mid-1980s, the share of studies titled with 'water market/trade' has grown less than proportionally to the total number of water market-related studies, suggesting a diversification of academic investigations from water markets per se to a broader variety of related issues.

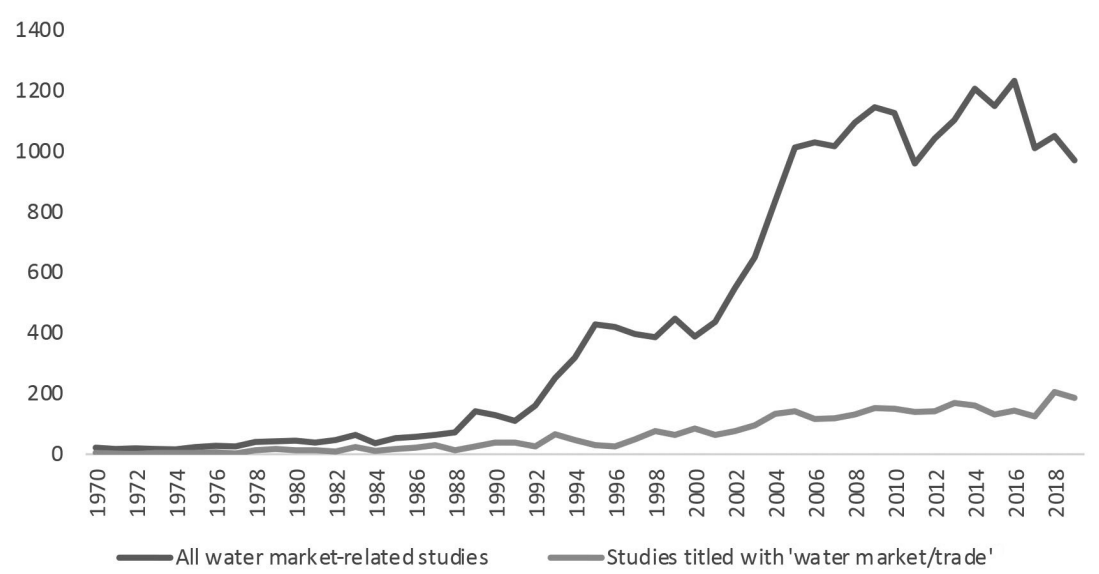

Figure 1.2 Cumulative number of studies in the water market/trade related literature, 1970-2019

Figure 1.3 shows the publication number trend. The annual average number of water market-related studies has increased from 0.4 in the 1970s to 23.2 in the 2010s. In the 2000s, the annual number of water market/trade-related studies increased significantly.

Most of these publications focus on water market issues in Australia (164 studies), which is the driest continent in the world. The United States (mostly the western states) receives the second-largest share of this literature (128 studies). China also has a significant share of the literature (33 studies), most of which were published in the 2010s. Studies on these three countries consist of more than 71 per cent of the selected publications.

Figure 1.4 presents the regional distribution of study contexts, where general water market investigations (without a specific country focus) are excluded. It is seen that most studies are on countries where certain regions face significant water resource constraints. 


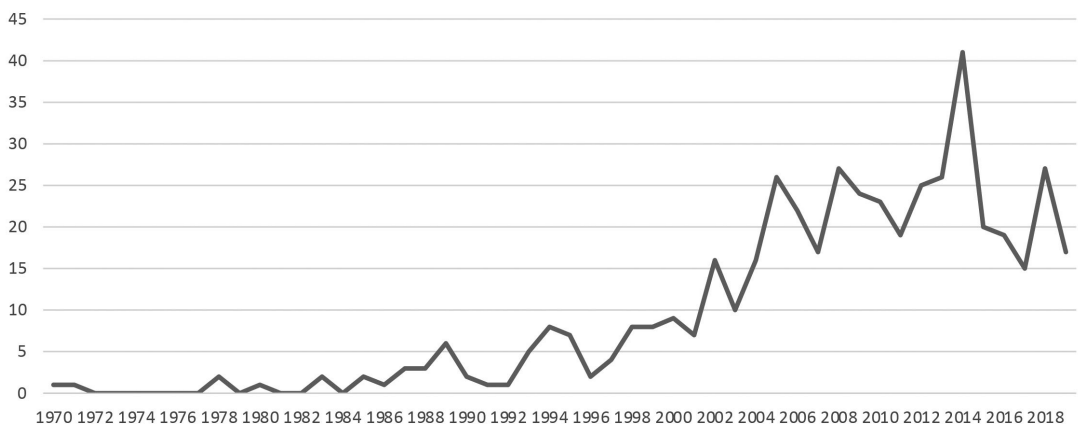

Figure 1.3 Number of annual relevant studies in the water market/trade literature, 1970-2019

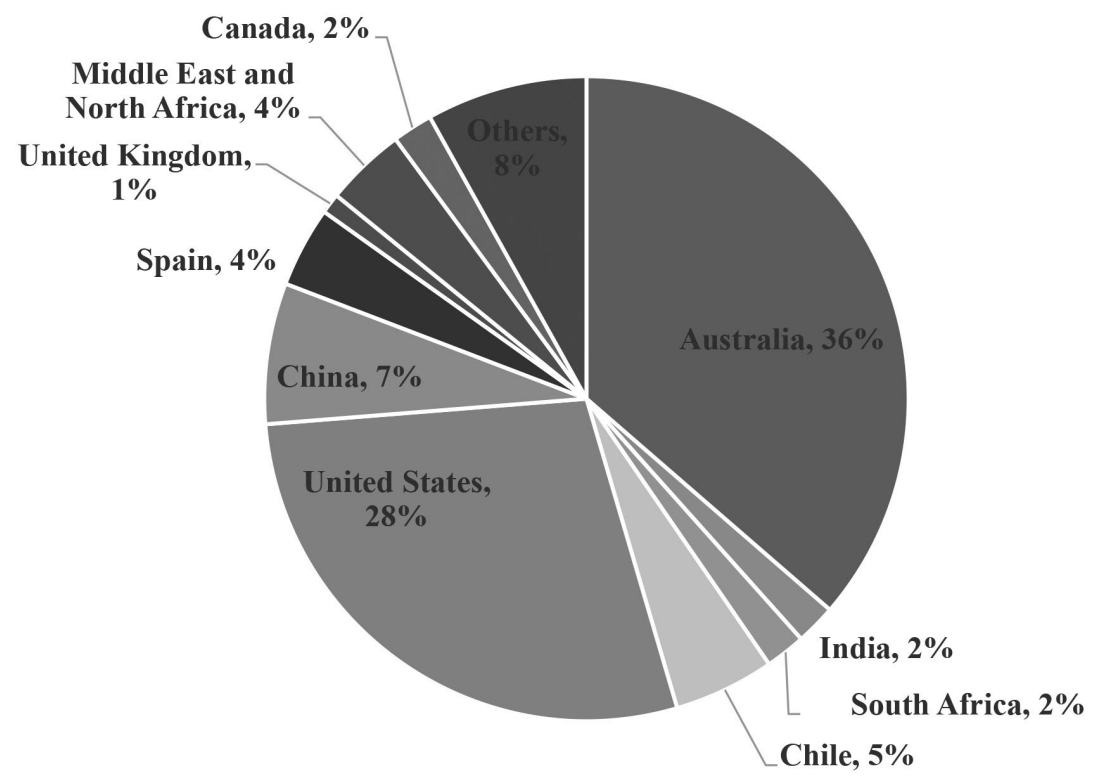

Figure 1.4 Regional distribution of water market study contexts, 1970-2019

The type of water market (for example, rural, urban, other - no specific focus) was identified from 458 publications: 259 studies investigated rural water markets, focusing particularly on agricultural water use and management; 22 
studies studied water demand/consumption issues in urban areas; while 71 studies jointly considered both rural and urban areas to investigate water distribution issues among different production/consumption sectors. The remainder had no specific rural or urban focus.

Regarding analytical approaches, in our review of the water market literature, 210 studies ( 43.9 per cent) used qualitative methods and 261 studies (54.6 per cent) employed quantitative tools including theoretical economic modelling, optimization, simulation and econometric methods. A mixed-methods approach was used by 0.4 per cent of studies; and 1.1 per cent were literature syntheses.

Water market studies are published across a variety of disciplines. According to the Web of Science journal classifications, popular journal categories included Water Resources (253 studies), Economics (122 studies), Environmental Sciences (45 studies), Agricultural Economics and Policy (76 studies), Law (27 studies) and Development Studies (24 studies), among others (double-counting applies, as most journals are classified into two or more categories). Popular outlets included: Water Policy (27 studies), Water Resources Research (25 studies), Agricultural Water Management (23 studies), Australian Journal of Agricultural and Resource Economics (18 studies), Journal of Hydrology (17 studies), Ecological Economics (14 studies), International Journal of Water Resources Development (12 studies), Natural Resources Journal (11 studies), American Journal of Agricultural Economics (11 studies), Water International (10 studies) and Journal of Environmental Management (9 studies), among others.

Popular research topics of selected publications are presented in Table 1.1. There has been a wide variety of different research questions investigated in the literature, from understanding important preconditions for water markets, to analysing water market price and volume drivers, to understanding net overall benefits from water markets.

\subsection{THIS BOOK}

Given the increasing interest in water markets and the growing water market literature, Wheeler et al. (2017; which is republished with minor changes in Chapter 2) sought to develop an assessment framework for evaluating the practical benefits and institutional bases for the implementation and sustainability of water markets to address scarcity issues, called the water market readiness assessment (WMRA) framework. The WMRA consisted of three institutional factors as a prerequisite for establishing water markets:

1. Step one: enabling institutions. Defining the total resource pool available for consumptive use and hydrological factors of use; and evaluating 

Table $1.1 \quad$ Popular research topics in the water market literature,
1970-2019

\begin{tabular}{|c|c|c|}
\hline Research topic & $\begin{array}{l}\text { Typical } \\
\text { approach }\end{array}$ & Some examples (not exhaustive) \\
\hline $\begin{array}{l}\text { Feasibility of } \\
\text { introducing } \\
\text { water market(s) } \\
\text { and framework } \\
\text { assessment }\end{array}$ & Qualitative & $\begin{array}{l}\text { Zarour and Isaac, 1993; Becker and Zeitouni, 1998; Bjornlund and } \\
\text { McKay, 2000; Bate, 2002; Bjornlund, 2003; Vasquez, 2008; Grafton } \\
\text { et al., 2011; Akram, 2013; Kirsch and Maxwell, 2015; Grafton et al., } \\
\text { 2016; Prieto, 2016; Wheeler et al., 2017; Petterini, } 2018\end{array}$ \\
\hline $\begin{array}{l}\text { Water market } \\
\text { performance }\end{array}$ & $\begin{array}{l}\text { Qualitative } \\
\text { and } \\
\text { quantitative }\end{array}$ & $\begin{array}{l}\text { McCarl et al., 1999; Neuman and Chapman, 1999; Mahan et al., } \\
\text { 2002; Newlin et al., 2002; Zekri and Easter, 2005; Pujol et al., 2006; } \\
\text { Bauer, 2010; Culp et al., 2014; Grafton and Horne, 2014; Wheeler, } \\
\text { 2014; Wheeler et al., 2014; Bauer, 2015; Leonard et al., } 2019\end{array}$ \\
\hline $\begin{array}{l}\text { Privatisation and } \\
\text { marketisation of } \\
\text { the water sector }\end{array}$ & Qualitative & $\begin{array}{l}\text { Glennon, 2004; Borzutzky and Madden, 2013; Glennon, 2015; } \\
\text { Grafton et al., } 2016\end{array}$ \\
\hline $\begin{array}{l}\text { Water market } \\
\text { policy evaluation }\end{array}$ & $\begin{array}{l}\text { Qualitative } \\
\text { and } \\
\text { quantitative }\end{array}$ & $\begin{array}{l}\text { Rosegrant et al., 1995; Brennan, 2006; van Heerden et al., 2008; } \\
\text { Garrick and Aylward, 2012; Garrick et al., 2013; Jamshidi et al., } \\
2016\end{array}$ \\
\hline $\begin{array}{l}\text { Water demand and } \\
\text { price analysis }\end{array}$ & Quantitative & $\begin{array}{l}\text { Zarnikau, 1994; Saleth and Dinar, 2001; Ipe and Bhagwat, 2002; } \\
\text { Yoskowitz, 2002; Garcia et al., 2005; Gulyani et al., 2005; } \\
\text { Zilberman and Schoengold, 2005; Pullen and Colby, 2008; Wheeler } \\
\text { et al., 2008a; Zuo et al., 2019: Schwabe et al., } 2020\end{array}$ \\
\hline $\begin{array}{l}\text { Farmers' } \\
\text { willingness to } \\
\text { pay for water } \\
\text { or participate in } \\
\text { water market }\end{array}$ & Quantitative & $\begin{array}{l}\text { Saleth and Dinar, 2001; Ranjan and Shogren, 2006; Giannoccaro } \\
\text { et al., 2015; Venkatachalam, 2015; Jaghdani and Brümmer, 2016; } \\
\text { Wheeler et al., 2009, } 2010\end{array}$ \\
\hline $\begin{array}{l}\text { Human behaviour } \\
\text { in water markets }\end{array}$ & $\begin{array}{l}\text { Quantitative } \\
\text { (experimental) }\end{array}$ & $\begin{array}{l}\text { Lefebvre et al., 2012; Broadbent et al., 2014; Hansen et al., 2014; } \\
\text { Nauges et al., } 2016\end{array}$ \\
\hline $\begin{array}{l}\text { Institutional } \\
\text { arrangements and } \\
\text { transaction costs }\end{array}$ & $\begin{array}{l}\text { Qualitative } \\
\text { and } \\
\text { quantitative }\end{array}$ & $\begin{array}{l}\text { Howitt, 1994; Shatanawi and Al-Jayousi, 1995; Nieuwoudt, 2000; } \\
\text { Carey et al., 2002; Hadjigeorgalis and Lillywhite, 2004; Zhang et al., } \\
\text { 2009; Zhao et al., 2013; Erfani et al., 2014; Breviglieri et al., 2018; } \\
\text { Loch et al., } 2018\end{array}$ \\
\hline $\begin{array}{l}\text { Case studies: } \\
\text { water market } \\
\text { successes and } \\
\text { failures }\end{array}$ & $\begin{array}{l}\text { Qualitative } \\
\text { and } \\
\text { quantitative }\end{array}$ & $\begin{array}{l}\text { Burness and Quirk, 1980; Yoskowitz, 1999; Bakker, 2002; Zegarra, } \\
\text { 2002; Bauer, 2010; Zavalloni et al., 2014; Bauer, } 2015\end{array}$ \\
\hline $\begin{array}{l}\text { Water trade } \\
\text { modelling }\end{array}$ & Quantitative & $\begin{array}{l}\text { Louw and van Schalkwyk, 2001; Turral et al., 2005; Zaman et al., } \\
\text { 2009; Alevy et al., 2010; Loch et al., 2011; Wittwer, 2011; Hung et } \\
\text { al., 2014; Regnacq et al., 2016; Wheeler et al., 2008a, 2008b; Zuo } \\
\text { et al., } 2019\end{array}$ \\
\hline
\end{tabular}




\begin{tabular}{|c|c|c|}
\hline Research topic & $\begin{array}{l}\text { Typical } \\
\text { approach }\end{array}$ & Some examples (not exhaustive) \\
\hline $\begin{array}{l}\text { Design of water } \\
\text { rights }\end{array}$ & $\begin{array}{l}\text { Qualitative } \\
\text { and } \\
\text { quantitative }\end{array}$ & $\begin{array}{l}\text { Johnson, 1971; Shupe et al., 1989; Michelsen and Young, 1993; } \\
\text { Rosegrant and Binswanger, 1994; Ríos and Quiroz, 1995; } \\
\text { Matthews, 2004; Solanes and Jouravlev, 2006; Whitford and Clark, } \\
\text { 2007; Donohew, 2009; McKenzie, 2009; Nordblom et al., 2011; } \\
\text { Raffensperger, 2011; Lefebvre et al., 2012; Jamshidi et al., 2016; } \\
\text { Young, } 2019\end{array}$ \\
\hline $\begin{array}{l}\text { Inter-state water } \\
\text { governance }\end{array}$ & Qualitative & Utton, 1985; Rodgers, 1986; Wheeler, 2014 \\
\hline $\begin{array}{l}\text { Water use } \\
\text { efficiency }\end{array}$ & Quantitative & Srivastava et al., 2009; Manjunatha et al., 2011; Razzaq et al., 2019 \\
\hline $\begin{array}{l}\text { Environmental } \\
\text { impacts }\end{array}$ & Quantitative & Tisdell, 2001; Lee et al., 2007; Rambonilaza and Neang, 2019 \\
\hline $\begin{array}{l}\text { Climate impacts } \\
\text { on water markets }\end{array}$ & $\begin{array}{l}\text { Qualitative } \\
\text { and } \\
\text { quantitative }\end{array}$ & $\begin{array}{l}\text { Pullen and Colby, 2006; Adler, 2008; Wheeler et al., 2008a, 2008b, } \\
\text { 2013; Kahil et al., 2015; Ghosh, 2019; Zuo et al., } 2019\end{array}$ \\
\hline $\begin{array}{l}\text { Indigenous water } \\
\text { rights/markets }\end{array}$ & $\begin{array}{l}\text { Qualitative } \\
\text { and } \\
\text { quantitative }\end{array}$ & $\begin{array}{l}\text { Nikolakis et al., 2013; von der Porten and de Loë, 2014; Nikolakis } \\
\text { and Grafton, 2015; Taylor et al., 2016; Poirier and Schartmueller, } \\
2012\end{array}$ \\
\hline $\begin{array}{l}\text { Water quality } \\
\text { trade }\end{array}$ & $\begin{array}{l}\text { Qualitative } \\
\text { and } \\
\text { quantitative }\end{array}$ & Uchida et al., 2018; Leonard et al., 2019 \\
\hline $\begin{array}{l}\text { Informal water } \\
\text { markets }\end{array}$ & $\begin{array}{l}\text { Qualitative } \\
\text { and } \\
\text { quantitative }\end{array}$ & $\begin{array}{l}\text { Brozovic et al., 2002; Garrick et al., 2019; Munala and Kainz, 2012; } \\
\text { Sima et al., 2013; Venkatachalam, 2015; Jaghdani and Brümmer, } \\
\text { 2016; Razzaq et al., } 2019\end{array}$ \\
\hline
\end{tabular}

the current institutional, legislative, planning and regulatory capacity to facilitate water trade, involving: (a) specifying each resource share in perpetuity while allowing for changes in the proportion allocated to each share (comprises setting caps and regulations on use); (b) fully assigning responsibility for managing supply risk to users; (c) ensuring enforcement, strict regulation of caps and monitoring/compliance; and (d) keeping transaction costs low.

2. Step two: facilitating gains from trade. Developing clear and consistent trading rules; assessing benefits and costs of market-based reallocation; for example, numbers of individuals who can trade (versus adoption of trade); homogeneity of water use, adaptation benefits, cost of water reform, ongoing trade transaction costs and assessment of externalities. There is a difference between legislating for water trade to occur, allowing transfers between a small number of individuals, versus broader water reform legislation (for example, creating water registers with transparent, 
complete and fully accessible data, clearer trade rules, public information sources).

3. Step three: monitoring and enforcement. Use of water markets and water extractions need ongoing monitoring and enforcement to ensure compliance, as well as continued development of trade-enabling mechanisms, including: seeking to limit/reduce transaction costs, scanning for unanticipated externalities, developing new market products (for example, option contracts or forwards) and then implementing, if needed, new legislative changes and planning requirements. Water market rules need flexibility to ensure water security and manage future uncertainty (Wheeler et al., 2017).

The institutional framework factors outlined in steps one and three above are needed for any property rights regime, while step two lists specific institutional factors required for water markets in particular. Given that water markets are complex economic instruments to design, develop, implement and sustain over time, and the fact that many countries have started to consider water markets as a management tool, there is a need for further testing of the WMRA framework to validate its robustness and practical usefulness in the field, particularly in developing-nation contexts with relatively weak institutional arrangements.

The purpose of this book is thus to apply the WMRA framework in a wider range of contextual applications across as many different countries as possible. This extended WMRA application is aimed at providing detailed insights and lessons for other countries going forward. The country case study chapters sought to apply the WMRA framework in different contexts and wherever possible to identify (as examples): (1) the local policy and practical management attitudes toward water markets, and whether there is any understanding/ willingness to explore water market capacity to deal with river basins under scarcity stress; (2) relevant stages of water reforms toward market-based economic instruments, and whether other approaches might be more feasible/ appropriate; and (3) detailed examinations of particular aspects of the WMRA framework to identify current gaps or requirements for reform if markets are to be established and sustained over time.

\subsubsection{Water Market Case Studies Explored in this Book}

The chapters written by water policy expert scholars in this book span six continents, across 20 countries. Chapter 2 presents the original journal article of the WMRA framework, and this journal article undertook case studies of Tasmania, Spain and the Diamond Valley in the United States of America (USA). Following Chapter 2, the chapters are arranged by continent, namely: Africa, Asia, Europe, South America, North America and Oceania. 
More specifically, in Chapter 3 Jamie Pittock and co-authors explore the presence and use of water markets in Mozambique, Tanzania and Zimbabwe. Alec Zuo and co-authors apply the WRMA framework to water markets in Zhangye City, China in Chapter 4; while Sophie Lountain and co-authors look at groundwater markets in West Bengal, India in Chapter 5. In Chapter 6, Kate Reardon-Smith and co-authors investigate water governance conditions in the Lower Mekong Basin, in particular for the countries of Myanmar, Lao, Cambodia, Thailand and Vietnam. In Chapter 7, Andrew Johnson and co-authors discuss Nepal's water management challenges; and in Chapter 8 Irfan Baig and co-authors discuss groundwater markets in the Indus Basin Irrigation System, Pakistan.

Chapter 9 by Simon and Arnaud de Bonviller discusses the extent to which water markets are implemented in France in the areas of Poitou Marsh Basin and the Neste system; and in Chapter 10 Carlos Pérez-Blanco provides an overview of the development of water markets in Italy, particularly focussing on the Po River Basin District. Chapter 11 by Rosalind Bark and Nancy Smith looks at water markets in England. Chapter 12 by Guillermo Donoso and co-authors summarises Chile's experiences with water markets.

Chapter 13 by Gina Gilson and Dustin Garrick looks at the growth of environmental water markets in the Columbia Basin (USA); while in Chapter 14 Julia Talbot-Jones and Quentin Grafton study water markets in Canterbury, New Zealand.

Chapter 15 summarises the key lessons learnt from all the case studies that have applied the WMRA framework, as well as providing a quantitative overview of the progress towards fully functioning water markets around the world.

Overall, we hope that this book will allow water professionals to more fully comprehend the practical issues associated with assessing water market implementation and, if desired and feasible, how to ensure their continued development for improved societal well-being and water allocation over time.

\section{REFERENCES}

Adler, J.H. (2008). Water marketing as an adaptive response to the threat of climate change. Hamline Law Review, 31(3), 729-754.

Akram, A.A. (2013). Is a surface-water market physically feasible in Pakistan's Indus Basin Irrigation System? Water International, 38(5), 552-570.

Alevy, J.E., Cristi, O., and Melo, O. (2010). Right-to-choose auctions: a field study of water markets in the Limari valley of Chile. Agricultural and Resource Economics Review, 39(1203-2016-95457), 213-226.

Bakker, K. (2002). From state to market? Water mercantilización in Spain. Environment and Planning A, 34(5), 767-790. 
Barbier, E. (2019). The Water Paradox: Overcoming the Global Crisis in Water Management. Yale University Press.

Bate, R. (2002). Water: can property rights and markets replace conflict. In J. Morris (ed.), Sustainable Development: Promoting Progress or Perpetuating Poverty (pp. 1-16). Profile Books.

Bauer, C. (2010). Market approaches to water allocation: lessons from Latin America. Journal of Contemporary Water Research and Education, 144(1), 44-49.

Bauer, C.J. (2015). Water conflicts and entrenched governance problems in Chile's market model. Water Alternatives, 8(2), 147-172.

Becker, N., and Zeitouni, N. (1998). A market solution for the Israeli-Palestinian water dispute. Water International, 23(4), 1-5.

Bjornlund, H. (2003). Efficient water market mechanisms to cope with water scarcity. Water Resources Development, 19(4), 553-567.

Bjornlund, H., and McKay, J. (2000). Do water markets promote a socially equitable reallocation of water? A case study of a rural water market in Victoria, Australia. Rivers, 7(2), 141-154.

Borzutzky, S., and Madden, E.F. (2013). Markets awash: the privatization of Chilean water markets. Journal of International Development, 25(2), 251-275.

Brennan, D. (2006). Water policy reform in Australia: lessons from the Victorian seasonal water market. Australian Journal of Agricultural and Resource Economics, 50(3), 403-423.

Breviglieri, G.V., do Sol Osório, G.I., and Puppim de Oliveira, J.A. (2018). Understanding the emergence of water market institutions: learning from functioning water markets in three countries. Water Policy, 20(6), 1075-1091.

Broadbent, C.D., Brookshire, D.S., Coursey, D., and Tidwell, V. (2014). An experimental analysis of water leasing markets focusing on the agricultural sector. Agricultural Water Management, 142, 88-98.

Brozovic, N., Carey, J.M., and Sunding, D.L. (2002). Trading activity in an informal agricultural water market: an example from California. Water Resources Update, 121(1), 3-16.

Burness, H.S., and Quirk, J.P. (1980). Water law, water transfers, and economic efficiency: the Colorado River. Journal of Law and Economics, 23(1), 111-134.

Carey, J., Sunding, D.L., and Zilberman, D. (2002). Transaction costs and trading behavior in an immature water market. Environment and Development Economics, 7(4), 733-750.

Chong, H., and Sunding, D. (2006). Water markets and trading. Annual Review of Environmental Resource Economics, 31, 239-264.

Culp, P.W., Glennon, R.J., and Libecap, G. (2014). Shopping for Water: How the Market can Mitigate Water Shortages in the American West. Island Press.

De Stefano L., and Hernández-Mora N. (2016). Los mercados informales de aguas en españa: una visión de conjunto. In J. Gómez-Limón and J. Calatrava (eds), Los Mercados de Agua en España: Presente Y Perspectivas (pp. 95-121). Cajamar Caja Rural, Amería.

Dinar, A., Rosegrant, M.W., and Meinzen-Dick, R. (1997). Water allocation mechanisms: principles and examples. Policy Research Working Paper, World Bank, no. 1779. http://elibrary.worldbank.org/doi/abs/10.1596/1813-9450-1779.

Donohew, Z. (2009). Property rights and western United States water markets. Australian Journal of Agricultural and Resource Economics, 53(1), 85-103.

Easter, K., and Huang, Q. (eds) (2014). Water Markets for the 21 st Century. Springer. 
Easter, K., Rosegrant, M., and Dinar, A. (1998). Markets for Water: Potential and Performance. Natural Resource Management and Policy series. Kluwer Academic Publishers.

Easter, K., Rosegrant, M., and Dinar, A. (1999). Formal and informal markets for water: institutions, performance, and constraints. World Bank Research Observer, 14(1), 99-116.

Erfani, T., Binions, O., and Harou, J.J. (2014). Simulating water markets with transaction costs. Water Resources Research, 50(6), 4726-4745.

Garcia, S., Guérin-Schneider, L., and Fauquert, G. (2005). Analysis of water price determinants in France: cost recovery, competition for the market and operator's strategy. Water Science and Technology: Water Supply, 5(6), 173-181.

Garrick, D., and Aylward, B. (2012). Transaction costs and institutional performance in market-based environmental water allocation. Land Economics, 88(3), 536-560.

Garrick, D., De Stefano, L., Yu, W., Jorgensen, I., O’Donnell, E., et al. (2019). Rural water for thirsty cities: a systematic review of water reallocation from rural to urban regions. Environmental Research Letters, 14(4), 043003.

Garrick, D., Whitten, S.M., and Coggan, A. (2013). Understanding the evolution and performance of water markets and allocation policy: a transaction costs analysis framework. Ecological Economics, 88, 195-205.

Ghosh, S. (2019). Droughts and water trading in the western United States: recent economic evidence. International Journal of Water Resources Development, 35(1), $145-159$.

Giannoccaro, G., Castillo, M., and Berbel, J. (2015). An assessment of farmers' willingness to participate in water trading in southern Spain. Water Policy, 17(3), 520-537.

Glennon, R. (2004). Water scarcity, marketing, and privatization. Texas Law Review, $83,1873$.

Glennon, R. (2015). Should farm communities support water markets? Western Farm Press, 8 May.

Gómez Gómez, C.M., Pérez-Blanco, C.D., Adamson, D., and Loch, A. (2018). Managing water scarcity at a river basin scale with economic instruments. Water Economics and Policy, 4(1), 1750004. DOI: 10.1142/S2382624X17500047.

Grafton, R.Q., and Horne, J. (2014). Water markets in the Murray-Darling basin. Agricultural Water Management, 145(C), 61-71.

Grafton, R.Q., and Wheeler, S.A. (2015). Water economics. In R. Halvorsen and D. Layton (eds), Handbook on the Economics of Natural Resources (pp. 401-420). Edward Elgar Publishing.

Grafton, R.Q., Horne, J., and Wheeler, S.A. (2016). On the marketisation of water: evidence from the Murray-Darling Basin, Australia. Water Resources Management, 30(3), 913-926.

Grafton, R.Q., Libecap, G., McGlennon, S., Landry, C., and O’Brien, B. (2011). An integrated assessment of water markets: a cross-country comparison. Review of Environmental Economics and Policy, 5(2), 219-239.

Grafton, R.Q., Williams, J., Perry, C.J., Molle, F., Ringler, C., et al. (2018). The paradox of irrigation efficiency. Science, 361(6404), 748-750.

Griffin, R.C. (2006). Water Resource Economics: The Analysis of Scarcity, Policies, and Projects. MIT Press.

Griffin, R.C., Peck, D.E., and Maestu, J. (2013). Introduction: myths, principles and issues in water trading. In J. Maestu (ed.), Water Trading and Global Water Scarcity: International Experiences (pp. 1-14). RFF Press Water Policy Series. 
Gulyani, S., Talukdar, D., and Mukami Kariuki, R. (2005). Universal (non) service? Water markets, household demand and the poor in urban Kenya. Urban Studies, 42(8), 1247-1274.

Hadjigeorgalis, E., and Lillywhite, J. (2004). The impact of institutional constraints on the Limarí River Valley water market. Water Resources Research, 40(5), 752-1688.

Hanemann, W.H. (2006). The economic conception of water. In P.P. Rogers, M.R. Llamas and L. Martinez-Cortina (eds), Water Crisis: Myth or Reality? (pp. 61-91). Taylor \& Francis.

Hansen, K., Kaplan, J., and Kroll, S. (2014). Valuing options in water markets: a laboratory investigation. Environmental and Resource Economics, 57(1), 59-80.

Howe, C., Schurmeier, D., and Shaw Jr, W. (1986). Innovative approaches to water allocation: the potential for water markets. Water Resources Research, 22(4), 439-445.

Howitt, R.E. (1994). Empirical analysis of water market institutions: the 1991 California water market. Resource and Energy Economics, 16(4), 357-371.

Hung, M.F., Shaw, D., and Chie, B.T. (2014). Water trading: locational water rights, economic efficiency, and third-party effect. Water, 6(3), 723-744.

Ipe, V.C., and Bhagwat, S.B. (2002). Chicago's water market: dynamics of demand, prices and scarcity rents. Applied Economics, 34(17), 2157-2163.

Jaghdani, T., and Brümmer, B. (2016). Determinants of willingness to pay for groundwater: insights from informal water markets in Rafsanjan, Iran. International Journal of Water Resources Development, 32(6), 944-960.

Jamshidi, S., Ardestani, M., and Hossein Niksokhan, M. (2016). A seasonal waste load allocation policy in an integrated discharge permit and reclaimed water market. Water Policy, 18(1), 235-250.

Johnson, D.D. (1971). An optimal state water law: fixed water rights and flexible market prices. Virginia Law Review, 57(3), 345-374.

Kahil, M.T., Dinar, A., and Albiac, J. (2015). Modeling water scarcity and droughts for policy adaptation to climate change in arid and semiarid regions. Journal of Hydrology, 522, 95-109.

Kirsch, B.R., and Maxwell, R.M. (2015). The use of a water market to minimize drought-induced losses in the Bay Area of California. Journal - American Water Works Association, 107(5), E274-E281.

Lee, L.Y., Ancev, T., and Vervoort, W. (2007). Environmental and economic impacts of water scarcity and market reform on the Mooki catchment. Environmentalist, 27(1), 39-49.

Lefebvre, M., Gangadharan, L., and Thoyer, S. (2012). Do security-differentiated water rights improve the performance of water markets? American Journal of Agricultural Economics, 94(5), 1113-1135.

Leonard, B., Costello, C., and Libecap, G.D. (2019). Expanding water markets in the western United States: barriers and lessons from other natural resource markets. Review of Environmental Economics and Policy, 13(1), 43-61.

Loch, A., Bjornlund, H., and McIver, R. (2011). Achieving targeted environmental flows: alternative allocation and trading models under scarce supply - lessons from the Australian reform process. Environment and Planning C: Government and Policy, 29(4), 745-760.

Loch, A., Wheeler, S.A., and Settre, C. (2018). Private transaction costs of water trade in the Murray-Darling Basin. Ecological Economics, 146, 560-573.

Louw, D.B., and Van Schalkwyk, H.D. (2001). The impact of transaction costs on water trade in a water market allocation regime. Agrekon, 40(4), 780-793. 
Maestu, J. (ed.) (2013). Water Trading and Global Water Scarcity: International Experiences. RFF Press Water Policy Series.

Mahan, R.C., Horbulyk, T.M., and Rowse, J.G. (2002). Market mechanisms and the efficient allocation of surface water resources in southern Alberta. Socio-Economic Planning Sciences, 36(1), 25-49.

Manjunatha, A.V., Speelman, S., Chandrakanth, M.G., and Van Huylenbroeck, G. (2011). Impact of groundwater markets in India on water use efficiency: a data envelopment analysis approach. Journal of Environmental Management, 92(11), 2924-2929.

Matthews, O.P. (2004). Fundamental questions about water rights and market reallocation. Water Resources Research, 40(9). DOI: 10.1029/2003WR002836.

McCarl, B.A., Dillon, C.R., Keplinger, K.O., and Williams, R.L. (1999). Limiting pumping from the Edwards Aquifer: an economic investigation of proposals, water markets, and spring flow guarantees. Water Resources Research, 35(4), 1257-1268.

McKenzie, M. (2009). Water rights in NSW: properly property. Sydney Law Review, $31,443$.

Michelsen, A.M., and Young, R.A. (1993). Optioning agricultural water rights for urban water supplies during drought. American Journal of Agricultural Economics, 75(4), 1010-1020.

Mukherji, A. (2008). Spatio-temporal analysis of markets for groundwater irrigation services in India: 1976-1977 to 1997-1998. Hydrogeology Journal, 16(6), 1077-1087.

Munala, G., and Kainz, H. (2012). Managing interactions in the informal water market: the case of Kisumu, Kenya. Development in Practice, 22(3), 347-360.

Nauges, C., Wheeler, S.A., and Zuo, A. (2016). Elicitation of irrigators' risk preferences from observed behaviour. Australian Journal of Agricultural Resource Economics, 60(3), 442-458.

Neuman, J.C., and Chapman, C. (1999). Wading into the water market: the first five years of the Oregon Water Trust. Journal of Environmental Law and Litigation, 14(1), 135-184.

Newlin, B.D., Jenkins, M.W., Lund, J.R., and Howitt, R.E. (2002). Southern California water markets: potential and limitations. Journal of Water Resources Planning and Management, 128(1), 21-32.

Nieuwoudt, W.L. (2000). Water market institutions: lessons from Colorado. Agrekon, 39(1), 58-67.

Nikolakis, W., and Grafton, R.Q. (2015). Putting Indigenous water rights to work: the Sustainable Livelihoods Framework as a lens for remote development. Community Development, 46(2), 149-163.

Nikolakis, W.D., Grafton, R.Q., and To, H. (2013). Indigenous values and water markets: survey insights from northern Australia. Journal of Hydrology, 500, 12-20.

Nordblom, T.L., Reeson, A.F., Finlayson, J.D., Hume, I.H., Whitten, S.M., and Kelly, J.A. (2011). Price discovery and distribution of water rights linking upstream tree plantations to downstream water markets: experimental results. Water Policy, 13(6), 810-827.

Petterini, F.C. (2018). The possibility of a water market in Brazil. Economia, 19(2), 187-200.

Poirier, R., and Schartmueller, D. (2012). Indigenous water rights in Australia. Social Science Journal, 49(3), 317-324.

Prieto, M. (2016). Bringing water markets down to Chile's Atacama Desert. Water International, 41(2), 191-212. 
Pujol, J., Raggi, M., and Viaggi, D. (2006). The potential impact of markets for irrigation water in Italy and Spain: a comparison of two study areas. Australian Journal of Agricultural and Resource Economics, 50(3), 361-380.

Pullen, J.L., and Colby, B.G. (2008). Influence of climate variability on the market price of water in the Gila-San Francisco Basin. Journal of Agricultural and Resource Economics, 33(3), 473-487.

Quiggin, J. (2001). Environmental economics and the Murray-Darling river system. Australian Journal of Agricultural and Resource Economics, 45(1), 67-94.

Raffensperger, J.F. (2011). Matching users' rights to available groundwater. Ecological Economics, 70(6), 1041-1050.

Rambonilaza, T., and Neang, M. (2019). Exploring the potential of local market in remunerating water ecosystem services in Cambodia: an application for endogenous attribute non-attendance modelling. Water Resources and Economics, 25, 14-26.

Ranjan, R., and Shogren, J.F. (2006). How probability weighting affects participation in water markets. Water Resources Research, 42(8), 1-10.

Razzaq, A., Qing, P., Abid, M., Anwar, M., and Javed, I. (2019). Can the informal groundwater markets improve water use efficiency and equity? Evidence from a semi-arid region of Pakistan. Science of The Total Environment, 666, 849-857.

Regnacq, C., Dinar, A., and Hanak, E. (2016). The gravity of water: water trade frictions in California. American Journal of Agricultural Economics, 98(5), 1273-1294.

Ríos, M.A., and Quiroz, J.A. (1995). The market of water rights in Chile: major issues. Cuadernos de economía, 32(97), 317-345.

Rodgers, A.B. (1986). The limits of state activity in the interstate water market. Land and Water Law Review, 21, 357.

Rosegrant, M.W., and Binswanger, H.P. (1994). Markets in tradable water rights: potential for efficiency gains in developing country water resource allocation. World Development, 22(11), 1613-1625.

Rosegrant, M.W., Schleyer, R.G., and Yadav, S.N. (1995). Water policy for efficient agricultural diversification: market-based approaches. Food Policy, 20(3), 203-223.

Sadoff, C., Hall, J.W., Grey, D., Aerts, J.C.J.H., Ait-Kadi, M., et al. (2015). Securing Water, Sustaining Growth. Report of the GWP/OECD Task Force on Water Security and Sustainable Growth. Oxford University.

Saleth, R.M., and Dinar, A. (2001). Preconditions for market solution to urban water scarcity: empirical results from Hyderabad City, India. Water Resources Research, 37(1), 119-131.

Schwabe, K., Nemati, M., Landry, C., and Zimmerman, G. (2020). Water markets in the western United States: trends and opportunities. Water, 12(233), 1-15.

Shatanawi, M.R., and Al-Jayousi, O. (1995). Evaluating market-oriented water policies in Jordan: a comparative study. Water International, 20(2), 88-97.

Shupe, S.J., Weatherford, G.D., and Checchio, E. (1989). Western water rights: the era of reallocation. Natural Resources Journal, 29, 413.

Sima, L.C., Kelner-Levine, E., Eckelman, M.J., McCarty, K.M., and Elimelech, M. (2013). Water flows, energy demand, and market analysis of the informal water sector in Kisumu, Kenya. Ecological Economics, 87, 137-144.

Solanes, M., and Jouravlev, A. (2006). Water rights and water markets: lessons from technical advisory assistance in Latin America. Irrigation and Drainage: The Journal of the International Commission on Irrigation and Drainage, 55(3), 337-342.

Srivastava, S.K., Kumar, R., and Singh, R.P. (2009). Extent of groundwater extraction and irrigation efficiency on farms under different water-market regimes in central 
Uttar Pradesh. Agricultural Economics Research Review, 22(1). DOI: 10.22004/ ag.econ.57384.

Taylor, K.S., Moggridge, B.J., and Poelina, A. (2016). Australian Indigenous water policy and the impacts of the ever-changing political cycle. Australasian Journal of Water Resources, 20(2), 132-147.

Tisdell, J.G. (2001). The environmental impact of water markets: an Australian case-study. Journal of Environmental Management, 62(1), 113-120.

Turral, H.N., Etchells, T., Malano, H.M.M., Wijedasa, H.A., Taylor, P., et al. (2005). Water trading at the margin: the evolution of water markets in the Murray-Darling Basin. Water Resources Research, 41(7). DOI: 10.1029/2004WR003463.

Uchida, E., Swallow, S.K., Gold, A.J., Opaluch, J., Kafle, A., et al. (2018). Integrating watershed hydrology and economics to establish a local market for water quality improvement: a field experiment. Ecological Economics, 146, 17-25.

Utton, A.E. (1985). In search of an integrating principle for interstate water law: regulation versus the market place. Natural Resources Journal, 25(4), 985-1004.

van Heerden, J.H., Blignaut, J., and Horridge, M. (2008). Integrated water and economic modelling of the impacts of water market instruments on the South African economy. Ecological Economics, 66(1), 105-116.

Vasquez, J. (2008). Feasibility of a water market in Colombia. International Journal of Sustainable Development and Planning, 3(4), 394-400.

Vaux Jr, H.J., and Howitt, R.E. (1984). Managing water scarcity: an evaluation of interregional transfers. Water Resources Research, 20(7), 785-792.

Venkatachalam, L. (2015). Informal water markets and willingness to pay for water: a case study of the urban poor in Chennai City, India. International Journal of Water Resources Development, 31(1), 134-145.

von der Porten, S., and de Loë, R.C. (2014). Water policy reform and Indigenous governance. Water Policy, 16(2), 222-243.

Wheeler, S.A. (2014). Insights, lessons and benefits from improved regional water security and integration in Australia. Water Resources and Economics, 8, 57-78.

Wheeler, S.A., and Garrick, D. (2020). A tale of two water markets in Australia: lessons for understanding participation in formal water markets. Oxford Review of Economic Policy, 36(1), 132-153.

Wheeler, S.A., Bjornlund, H., Shanahan, M., and Zuo, A. (2008a). Factors influencing water allocation and entitlement prices in the Greater Goulburn Area of Australia. In Y. Villacampa, C.A. Brebbia and D. Prats Rico (eds), Sustainable Irrigation Management, Technologies and Policies II (pp. 63-71). WIT Press.

Wheeler, S., Bjornlund, H., Shanahan, M., and Zuo, A. (2008b). Price elasticity of water allocations demand in the Goulburn-Murray Irrigation District. Australian Journal of Agricultural and Resource Economics, 52(1), 37-55.

Wheeler, S., Bjornlund, H., Shanahan, M., and Zuo, A. (2009). Who trades water allocations? Evidence of the characteristics of early adopters in the Goulburn-Murray Irrigation District, Australia 1998-1999. Agricultural Economics, 40(6), 631-643.

Wheeler, S., Bjornlund, H., Zuo, A., and Shanahan, M. (2010). The changing profile of water traders in the Goulburn-Murray Irrigation District, Australia. Agricultural Water Management, 97(9), 1333-1343.

Wheeler, S.A., Garrick, D., Loch, A., and Bjornlund, H. (2013). Evaluating water market products to acquire water for the environment in Australia. Land Use Policy, $30(1), 427-436$. 
Wheeler, S.A., Loch, A., Crase, L., Young, M., and Grafton, R.Q. (2017). Developing a water market readiness assessment framework. Journal of Hydrology, 552, 807-820.

Wheeler, S.A., Loch, A., Zuo, A., and Bjornlund, H. (2014). Reviewing the adoption and impact of water markets in the Murray-Darling Basin, Australia. Journal of Hydrology, 518, 28-41.

Whitford, A.B., and Clark, B.Y. (2007). Designing property rights for water: mediating market, government, and corporation failures. Policy Sciences, 40(4), 335-351.

Wittwer, G. (2011). Confusing policy and catastrophe: buybacks and drought in the Murray-Darling Basin. Economic Record, 30(3), 289-430.

Yoskowitz, D.W. (1999). Spot market for water along the Texas Rio Grande: opportunities for water management. Natural Resources Journal, 39(2), 345-355.

Yoskowitz, D.W. (2002). Price dispersion and price discrimination: empirical evidence from a spot market for water. Review of Industrial Organization, 20(3), 283-289.

Young, R.A. (1986). Why are there so few transactions among water users? American Journal of Agricultural Economics, 68(5), 1143-1151.

Young, M. (2019). Sharing Water: The Role of Robust Water-Sharing Arrangements in Integrated Water Resources Management. Perspectives paper by Global Water Partnership. https://www.gwp.org/globalassets/global/toolbox/publications/perspective -papers/gwp-sharing-water.pdfhttps:/www.gwp.org/globalassets/global/toolbox/ publications/perspective-papers/gwp-sharing-water.pdf.

Zaman, A.M., Malano, H.M., and Davidson, B. (2009). An integrated water trading-allocation model, applied to a water market in Australia. Agricultural Water Management, 96(1), 149-159.

Zarnikau, J. (1994). Spot market pricing of water resources and efficient means of rationing water during scarcity (water pricing). Resource and Energy Economics, 16(3), 189-210.

Zarour, H., and Isaac, J. (1993). Nature's apportionment and the open market: a promising solution to the Arab-Israeli water conflict. Water International, 18(1), 40-53.

Zavalloni, M., Raggi, M., and Viaggi, D. (2014). Water harvesting reservoirs with internal water reallocation: a case study in Emilia Romagna, Italy. Journal of Water Supply: Research and Technology - AQUA, 63(6), 489-496.

Zegarra, E. (2002). Water Market and Coordination Failures: The Case of the Limari Valley in Chile. University of Wisconsin.

Zekri, S., and Easter, W. (2005). Estimating the potential gains from water markets: a case study from Tunisia. Agricultural Water Management, 72(3), 161-175.

Zhang, J., Zhang, F., Zhang, L., and Wang, W. (2009). Transaction costs in water markets in the Heihe River Basin in Northwest China. International Journal of Water Resources Development, 25(1), 95-105.

Zhao, J., Cai, X., and Wang, Z. (2013). Comparing administered and market-based water allocation systems through a consistent agent-based modeling framework. Journal of Environmental Management, 123, 120-130.

Zilberman, D., and Schoengold, K. (2005). The use of pricing and markets for water allocation. Canadian Water Resources Journal, 30(1), 47-54.

Zuo, A., Qiu, F., and Wheeler, S. (2019). Examining volatility dynamics, spillovers and government water recovery in Murray-Darling Basin water markets. Resource and Energy Economics, 58, 101113--1-101113-16. 